\title{
MOTIVASI, PRESTASI BELAJAR, DAN PELATIHAN KERJA KAITANNYA TERHADAP KREATIVITAS SISWA
}

\author{
Rika Wardi * \\ ABSTRACT
}

This study aims to determine the size of the influences of motivation, academic achievement, and job training on students' creativity (Prakerin) for 3rd State Vocational School of Pamekasan. This study was using a quantitative approach with the level of associative forms of causal explanation. Population of this study was students from grade XII that take Prakerin class in academic year 2012-2013. Sample was taken by using purposive sampling for grade XII who follow the industry practice (Prakerin) in Production and Services Unit (UPJ) School with total of 68 students. Technique of data collection was using questionnaires technique, documentations, and observation sheets. Data were analyzed using multiple linear regression analysis. The results show that creativity is influenced by motivation, academic achievement and job training by $44.9 \%$ while the remaining 55.1 $\%$ are influenced by factors other than the variable motivation, achievement and training . Keywords: motivation, learning achievement, job training, students'creativity

\section{PENDAHULUAN}

$\mathrm{P}$ esatnya perkembangan yang terjadi baik dalam bidang politik, ekonomi, ilmu pengetahuan, teknologi, budaya maupun dunia pendidikan, menyebabkan persaingan yang cukup ketat. Dengan demikian perlu mengembangkan dan meningkatkan kualitas sumber daya manusia. Maka tantangan utama bagi dunia pendidikan adalah bagaimana menyelenggarakan pendidikan untuk membentuk sumber daya manusia yang berkualitas diera global, sehingga memungkinkan peserta didik untuk mengembangkan bakat dan kemampuannya secara optimal.

Kenyatannya banyak siswa SMK yang kurang kreatif dan tidak dapat mengembangkan bakat dan kemampuannya secara optimal, hal ini juga terjadi pada sebagian siswa SMKN 3 Pamekasan. Berdasarkan pengakuan guru produktif bahwa sebagian siswa kurang kreatif dalam membuat produk baru, hal itu disebabkan siswa yang bersangkutan kurang memiliki motivasi, daya kreasi serta kurang cekatan dalam mengkombinasikan atau menghasilkan karya-karya yang menarik.

Saat ini dunia kerja maupun bisnis menuntut kita memiliki kreativitas yang tinggi untuk tetap eksis dalam ketatnya persaingan. Pentingnya kreativitas telah diakui secara luas. Maka dari itu sangatlah penting membuka dan menambah wawasan sejak dini kepada siswa mengenai pentingnya kreativitas. Siswa nantinya diharapkan menjadi orang yang siap terjun ke dunia bisnis serta kompeten atau profesional dalam dunia kerja.

Penelitian ini dilakukan untuk menguji kembali serta memberikan penguatan dan lebih melengkapi temuan penelitian tentang beberapa faktor yang mempengaruhi kreativitas siswa seperti yang telah dilakukan peneliti sebelumnya, sehingga penelitian ini

*) Guru SMK Negeri 3 Pamekasan 
digolongkan dalam penelitian justifikasi, yaitu merupakan penguatan dari penelitian sebelumnya. Berdasarkan penelitian terdahulu, terdapat beberapa faktor yang dapat meningkatkan kreativitas siswa diantaranya adalah motivasi, prestasi belajar, dan pelatihan kerja (latihan). Maka dari itu dirasa penting untuk diteliti kembali di SMKN 3 Pamekasan untuk menjawab permasalahan tentang adakah pengaruh motivasi, prestasi belajar, dan pelatihan kerja terhadap kreativitas siswa.

Motivasi merupakan komponen yang sangat penting dalam kehidupan sehari-hari utamanya dalam upaya seseorang memenuhi kebutuhannya. Apabila kebutuhan utamanya telah terpenuhi maka akan timbul kebutuhan lain yang belum pernah dimiliki. Definisi motivasi menurut Hasibuan (2007: 141) adalah kemauan untuk berjuang atau berusaha ke tingkat yang lebih tinggi menuju tercapainya tujuan organisasi dengan syarat tidak mengabaikan kemampuannya untuk memperoleh kepuasan dalam pemenuhan kebutuhan-kebutuhan pribadi. Sedangkan Nawawi (2001: 351) berpendapat bahwa motivasi suatu kondisi yang mendorong atau menjadi penyebab seseorang melakukan suatu perbuatan atau kegiatan yang berlangsung secara sadar.

Maslow (dalam Slavin, 2011: 102) mengusulkan hierarki kebutuhan, dalam hal ini kebutuhan yang lebih rendah harus dipuaskan setidaknya sebagian sebelum seseorang nantinya mencoba memuaskan kebutuhan yang lebih tinggi. Konsep penting yang dikenalkan Maslow adalah perbedaan kebutuhan defisiensi dan kebutuhan pertumbuhan, yaitu:

a. Kebutuhan defisiensi (deficiency needs), meliputi kebutuhan fisiologis, keselamatan, cinta dan harga diri.

b. Kebutuhan pertumbuhan (growth needs), seperti kebutuhan untuk mengetahui dan memahami sesuatu, menghargai keindahan atau bertumbuh, dan berkembang dengan dihargai orang lain

Teori pengharapan (expectancy theory) yang diungkapkan oleh Atkinson (dalam Slavin, 2011: ) merupakan teori motivasi yang didasarkan pada keyakinan bahwa upaya orang untuk berhasil tergantung pada harapan mereka terhadap imbalan

Hal-hal yang dapat dilakukan untuk meningkatkan motivasi pencapaian menurut McClelland dan Atkinson (Slavin, 2011: 11) meliputi :

1. Motivasi dan orientasi sasaran

2. Ketidakberdayaan yang dipelajari

3. Harapan guru dan pencapaian

4. Kecemasan dan pencapaian

Dalam proses pembelajaran prestasi belajar siswa tidak sama antara yang satu dengan yang lain, hal ini berkaitan dengan kemampuan serta seberapa besar mereka berupaya untuk mencapai prestasi belajar yang baik. Prestasi belajar terdiri dari dua kata yaitu prestasi dan belajar. Makna prestasi berarti hasil yang telah dicapai dari yang telah dilakukan. Menurut Tu'u (2004: 75) bahwa prestasi belajar adalah penguasaan pengetahuan atau keterampilan yang dikembangkan oleh mata pelajaran, lazimnya ditunjukkan dengan nilai tes atau angka nilai yang diberikan oleh guru. Syah (2007: 213) mengemukakan bahwa pada prinsipnya, pengungkapan hasil belajar ideal meliputi segenap ranah psikologis yang berubah sebagai akibat pengalaman dan proses belajar siswa. Namun demikian, pengungkapan perubahan tingkah laku seluruh ranah itu, khususnya ranah rasa murid, sangat sulit. Hal ini disebabkan perubahan hasil belajar itu ada yang bersifat intangible (tak dapat draba). Oleh karena itu yang dapat dilakukan guru adalah hanya mengambil cuplikan perubahan tingkah laku yang dianggap penting dan diharapkan dapat mencerminkan peruba- 
han yang terjadi sebagai hasil belajar siswa, baik yang berdimensi cipta dan rasa maupun berdimensi karsa.

Pelatihan dipandang sebagai faktor penting bagi individu dan organisasi. Hal ini didasarkan pada suatu pemikiran bahwa melalui kegiatan pelatihan, siswa dapat memperoleh tambahan pengetahuan, keterampilan dan pedoman berperilaku yang diperlukan untuk menunjang kesuksesan dalam mencapai kreativitas yang diharapkan. Definisi pelatihan menurut Rae (Sofyandi, 2008: 113) adalah suatu usaha untuk meningkatkan pengetahuan dan kemampuan karyawan dalam melaksanakan pekerjaannya lebih efektif dan efisien. Ada beberapa faktor yang perlu dipertimbangkan dan berperan dalam pelatihan menurut Rivai (2004: 240) antara lain : (1) Materi yang Dibutuhkan, (2) Metode yang Digunakan, (3) Kemampuan Instruktur Pelatihan, (4) Sarana atau Prinsip-Prinsip Pembelajaran, (5) Peserta Pelatihan, (6) Evaluasi Pelatihan. Menurut Hariandja (2002: 168), ada beberapa alasan penting untuk mengadakan pelatihan, yaitu: (1) Karyawan yang baru direkrut sering kali belum memahami secara benar bagaimana melakukan pekerjaan, (2) Perubahan-perubahan lingkungan kerja dan tenaga kerja, (3) Meningkatkan daya saing perusahaan dan memperbaiki produktivitas, (4) Menyesuaikan dengan peraturan-peraturan yang ada. Metode pelatihan harus sesuai dengan jenis pelatihan yang akan dilaksanakan dan dapat dikembangkan oleh semua perusahaan. Rivai (2004: 242) membedakan metode pelatihan menjadi dua metode, yaitu : (1) On the job training, yaitu memberikan petunjuk-petunjuk mengenai pekerjaan secara langsung saat bekerja untuk melatih karyawan bagaimana melaksanakan pekerjaan mereka sekarang, (2) Off the job training, yaitu metode pelatihan yang dilakukan diluar jam kerja. Prakerin dilaksanakan dengan tujuan untuk meningkatkan kompetensi keahlian siswa. Kurikulum SMK (Dikmenjur: 2008) menyebutkan: Prakerin adalah pola penyelenggaraan diklat yang dikelola bersama-sama antara SMK dengan industri/asosiasi profesi sebagai institusi pasangan (IP), mulai dari tahap perencanaan, pelaksanaan hingga evaluasi dan sertifikasi yang merupakan satu kesatuan program dengan menggunakan berbagai bentuk alternative pelaksanaan, seperti day release, block release, dan sebagainya.

Kreativitas perlu ditanamkan kepada anak didik kita sejak dini, agar mereka terlatih dan mampu mengembangkan karakter-karakter kewirausahaan serta siap terjun di masyarakat tanpa harus menunggu untuk mengisi lowongan pekerjaan yang disediakan dari pemerintah maupun pihak swasta. Kreativitas menurut Munandar (2004: 104) adalah kemampuan : (1) Untuk membuat kombinasi baru berdasarkan data informasi atau unsur yang ada, (2) berdasarkan data atau informasi yang tersedia, menemukan banyak kemungkinan jawaban terhadap suatu masalah, dimana penekanannya adalah pada kualitas, ketepatgunaan, dan keragaman jawaban, (3) yang mencerminkan kelancaran, keluwesan dan orisinilitas dalam berfikir serta kemampuan untuk mengelaborasi suatu gagasan. Robert Weisberg (Tilaar, 2012: 63) memberikan suatu definisi kerja: berfikir kreatif terjadi apabila secara intensional seseorang menghasilkan suatu produk baru atau ketika dia melaksanakan suatu tugas. Sedangkan menurut komite penasehat nasional bidang pendidikan kreatif dan pendidikan budaya yang diterjemahkan oleh Craft (2005: 291) menggambarkan kreativitas sebagai bentuk aktivitas imajinatif yang mampu menghasilkan sesuatu yang bersifat original, murni, asli dan memiliki nilai.

Beberapa temuan peneliti tentang kreativitas diantaranya Mariati (2006), menunjukkan bahwa pertanyaan divergen dalam latihan dan kegiatan pembelajaran dapat mengembangkan kreativitas siswa. Demikian juga dengan Cheng (2006) menunjukkan bahwa web- 
based collaborative learning instruction meningkatkan kreativitas bisnis mahasiswa, dan web-based collaborative learning instruction sesuai dan bermanfaat bahwa guru dapat mengaplikasikan pada instruksi mengajar mereka. Kisti dan Fardana (2012) menunjukkan bahwa kreativitas siswa dipengaruhi oleh Self efficacy, hal itu ditunjukkan nilai koefisien korelasi sebesar 0,479. Felissa dan Hadi (2012) menunjukkan bahwa adanya pengaruh motivasi terhadap kreativitas siswa dengan memberikan sumbangan 18.9\% dengan taraf signifikansi 0.008. Serta penelitian yang dilakukan oleh Lestari, Harnanik, Hadi (2012) menunjukkan bahwa prakerin, prestasi belajar dan lingkungan keluarga berpengaruh terhadap minat berwirausaha siswa sebesar 54,6\%.

Berdasarkan kajian pustaka diatas, peneliti merumuskan hipotesis sebagai berikut:

1. Diduga ada pengaruh signifikan motivasi terhadap kreativitas siswa.

2. Diduga ada pengaruh signifikan prestasi belajar mata diklat produktif terhadap kreativitas siswa.

3. Diduga ada pengaruh signifikan pelatihan kerja terhadap kreativitas siswa.

4. Diduga ada pengaruh signifikan motivasi, prestasi belajar, dan pelatihan kerja secara bersama-sama terhadap kreativitas siswa

\section{METODE PENELITIAN}

Pendekatan dalam penelitian ini adalah pendekatan kuantitatif tingkat eksplanasi asosiatif bentuk kausal. Variabel yang digunakan dalam penelitian ini terdapat tiga variabel bebas yang meliputi motivasi (X1), prestasi belajar (X2), dan pelatihan kerja (X3) serta variabel terikat yaitu kreativitas siswa (Y).

Populasi dalam penelitian ini adalah siswa kelas XII SMK Negeri 3 Pamekasan yang mengikuti praktek kerja industri (prakerin) tahun 2012 sebanyak 348, sampel yang diambil berdasarkan purposive sampling yaitu siswa kelas XII yang mengikuti praktek kerja industri (prakerin) di Unit Produksi dan Jasa (UPJ) sekolah sebanyak 68 orang. Pengumpulan data dilakukan dengan menggunakan kuesioner yang diberikan kepada siswa untuk mendapatkan data tentang variabel motivasi, dokumentasi untuk mendapatkan data tentang variabel prestasi belajar yaitu nilai rata-rata rapor mata diklat produktif semester IV dan pelatihan kerja yaitu nilai prakerin yang diperoleh dari industri atau tempat siswa mengikuti prakerin, serta lembar pengamatan untuk mendapatkan data tentang kreativitas siswa, kreativitas siswa dinilai/diamati oleh pimpinan Unit Produksi dan Jasa (UPJ) sekolah. Kuesioner maupun lembar pengamatan memakai skala Likert atau alternatif-alternatif jawaban dimulai dari angka 1 hingga 5.

Teknik analisis data menggunakan analisis regresi berganda untuk mengetahui besarnya pengaruh motivasi, prestasi belajar, dan pelatihan kerja terhadap kreativitas siswa. Adapun persamaan regresi linier berganda adalah sebagai berikut :

$$
\mathrm{Y}=\mathrm{a}+\mathrm{b} 1 \mathrm{X} 1+\mathrm{b} 2 \mathrm{X} 2+\mathrm{b} 3 \mathrm{X} 3+\mathrm{e}
$$

Keterangan:

$\mathrm{Y}=$ variabel terikat (kreativitas siswa)

$\mathrm{X} 1=$ variabel bebas I (motivasi)

X2 = variabel bebas II (prestasi belajar)

X3 = variabel bebas III (pelatihan kerja)

a $\quad=$ kostanta

$\mathrm{b} 1, \mathrm{~b} 2, \mathrm{~b} 3=$ koefisien regresi

$\mathrm{e}=$ error 
Analisis uji statistik yaitu uji F dan uji t. Uji F digunakan untuk menguji signifikansi pengaruh variabel motivasi, prestasi belajar, dan pelatihan kerja secara bersama-sama terhadap kreativitas siswa. Uji t digunakan untuk menguji signifikansi pengaruh motivasi, prestasi belajar, dan pelatihan kerja secara parsial terhadap kreativitas siswa.

\section{Hasil Penelitian}

\section{HASIL PENELITIAN DAN PEMBAHASAN}

1. Deskripsi Variabel Penelitian

a. Variabel Motivasi

Motivasi siswa SMKN 3 Pamekasan berdasarkan jawaban responden (siswa) pada variabel motivasi seperti yang tertuang dalam tabel 4.18 mengenai rekapitulasi distribusi frekuensi variabel motivasi diperoleh nilai rata-rata variabel sebesar 4.09 termasuk kategori tinggi, serta hampir $90 \%$ siswa memiliki motivasi yang cenderung tinggi.

Hal ini berarti bahwa tingginya motivasi siswa tersebut disebabkan karena kebutuhan-kebutuhan siswa baik kebutuhan akan belajar, tersedianya sarana, dihargai maupun rasa aman dapat terpenuhi yaitu dengan pemanfaatan perpustakaan sebagai salah satu sumber pembelajaran dan sarana utamanya yang menunjang mata diklat produktif secara optimal maupun keaktifan siswa di dalam kelas serta selalu mentaati peraturan di sekolah. Adanya dorongan yang tinggi untuk mempergunakan potensi diri, berprestasi serta bersosialisasi dan bekerjasama dengan teman baik dari dalam dirinya sendiri maupun dari lingkungan yaitu dengan mengaplikasikan teori ke dalam praktek dan terdorong untuk berprestasi belajar baik serta dapat bekerja secara tim. Adanya harapan atau keyakinan yang tinggi terhadap keberhasilannya dalam proses belajar yaitu dengan mempunyai keyakinan bahwa pembelajaran sesuai minat, memperoleh manfaat dapat menyelesaikan pekerjaan dengan baik serta kondisi belajar dan bekerja yang baik.

Hal ini didukung penelitian yang dilakukan oleh Fadlilah (2011) menunjukkan adanya motivasi yang baik yang dimiliki siswa. Hal ini menunjukkan pentingnya motivasi siswa utamanya motivasi dari dalam siswa itu sendiri, seperti halnya pada penelitian yang dilakukan di SMK Negeri 3 Pamekasan dengan subjek penelitian siswa kelas XII yang mengikuti praktek kerja industri (prakerin) tahun 2012 di Unit Produksi dan Jasa (UPJ) sekolah. Dengan demikian motivasi yang tinggi akan memberikan kontribusi pada meningkatnya kreativitas siswa.

b. Variabel Prestasi Belajar

Prestasi belajar merupakan hasil belajar siswa yang diperoleh melalui proses pembelajaran yang ditunjukkan dengan angka nilai yang diberikan oleh guru yang tertuang dalam rapor. Rata-rata prestasi belajar siswa sebesar 77,37 dan nilai tersebut berada pada selang 74 sampai dengan 85 yang berarti nilai terendah yang diperoleh siswa adalah 74 dan nilai tertingginya adalah 85 . Prestasi belajar yang diperoleh siswa adalah lebih dari 75 yaitu sebanyak 56 orang $(82,35 \%)$ sedangkan prestasi belajar $\leq 75$ sebanyak 12 orang $(17,65 \%)$.

c. Variabel Pelatihan Kerja

Pelatihan kerja merupakan suatu bentuk program yang ditujukan untuk meningkatkan kinerja. Dalam hal ini pelatihan yang dilakukukan adalah dengan mengikutsertakan siswa dalam prakerin dengan tujuan untuk meningkatkan kreativitas mereka. rata-rata nilai pakerin siswa sebesar 79,49 dan nilai tersebut berada pada selang 75 sampai dengan 88 yang berarti nilai terendah yang diperoleh siswa adalah 75 dan nilai tertingginya 
adalah 88. nilai pelatihan kerja (prakerin) yang diperoleh siswa adalah lebih dari 75 yaitu sebanyak 57 orang $(83,82 \%)$ sedangkan nilai pelatihan kerja (prakerin) 75 sebanyak 11 orang $(16,18 \%)$.

d. Variabel Kreativitas

Kreativitas siswa SMKN 3 Pamekasan berdasarkan rekapitulasi distribusi frekuensi pada variabel kreativitas siswa diperoleh nilai rata-rata variabel sebesar 3,65 yang termasuk dalam kategori tinggi dan menunjukkan bahwa 75\% siswa memiliki kreativitas yang cenderung tinggi.

Kreativitas siswa dalam penelitian ini meliputi : memiliki rasa ingin tahu yang besar; sering mengajukan pertanyaan yang berbobot; memberikan banyak gagasan dan usul terhadap suatu masalah; mampu menyatakan pendapat secara spontan dan tidak malu-malu; mempunyai atau menghargai keindahan; mempunyai pendapat sendiri dan dapat mengungkapkannya, tidak mudah terpengaruh orang lain; memiliki rasa humor tinggi; mempunyai daya imajinasi yang kuat; mampu mengajukan pemikiran, gagasan pemecahan masalah yang berbeda dari orang lain (orisinil); dapat bekerja sendiri; senang mencoba hal-hal baru; mampu mengembangkan atau merinci suatu gagasan (kemampuan elaborasi).

\section{Uji Signifikan}

a. Persamaan regresi linier berganda

Model regresi yang diperoleh berdasarkan hasil penelitian, dapat dituliskan dalam bentuk persamaan regresi adalah sebagai berikut :

$\mathrm{Y}=-7,086+0,173 \mathrm{X} 1+0,055 \mathrm{X} 2+0,071 \mathrm{X} 3+\mathrm{e}$

Persamaan analisis regresi diatas mempunyai makna :

1. Konstanta (a) sebesar -7,086 menunjukkan bahwa besarnya kreativitas adalah -7,086 jika variabel motivasi, prestasi belajar dan pelatihan adalah nol atau konstan. Nilai kontanta yang bernilai negatif ini dapat berarti jika variabel motivasi, prestasi belajar dan pelatihan tidak memberikan kontribusi, maka nilai rata-rata dari kreativitas dianggap nol.

2. Koefisien regresi pada variabel motivasi (b1) sebesar 0,173 artinya jika motivasi naik satu satuan maka kreativitas akan naik sebesar 0,173 satuan dengan asumsi variabel prestasi belajar dan pelatihan kerja adalah konstan.

3. Koefisien regresi pada variabel prestasi belajar (b2) sebesar 0,055 artinya jika prestasi belajar belajar naik satu satuan maka kreativitas akan naik sebesar 0,055 satuan dengan asumsi variabel motivasi dan pelatihan kerja adalah konstan.

4. Koefisien regresi pada variabel pelatihan (b3) sebesar 0,071 artinya jika pelatihan naik satu satuan maka kreativitas akan naik sebesar 0,071 satuan dengan asumsi variabel motivasi dan prestasi belajar adalah konstan.

Ketiga variabel bebas memiliki koefisien regresi dengan arah yang positif, ini berarti bahwa peningkatan motivasi, prestasi belajar, dan pelatihan kerja akan meningkatkan kreativitas siswa.

b.Uji F (Uji Serentak) dan Nilai Koefisien Determinasi (R2)

Hasil uji F berdasarkan uji statistik F, diperoleh nilai F sebesar 17,371 dengan nilai signifikansi $\mathrm{p}=0,000$ lebih kecil dari 5\% sehingga dapat disimpulkan bahwa motivasi, prestasi belajar dan pelatihan secara simultan (bersama-sama) berpengaruh signifikan terhadap kreativitas siswa SMKN 3 Pamekasan. 
c. Uji t (Uji Individual) dan Nilai R2 Parsial

Adapun hasil uji t yang diperoleh adalah sebagai berikut :

1. Nilai t-hitung pada variabel motivasi (X1) sebesar 2,355 dengan tingkat signifikan kurang dari 5\% yaitu 0,022. Hal ini berarti motivasi (X1) secara parsial berpengaruh signifikan terhadap kreativitas (Y). Besarnya pengaruh motivasi (X1) terhadap kreativitas (Y) adalah 7,95\%.

2. Nilai t-hitung pada variabel prestasi belajar (X2) sebesar 2,869 dengan tingkat signifikan kurang dari 5\% yaitu 0,006. Hal ini berarti prestasi belajar (X2) secara parsial berpengaruh signifikan terhadap kreativitas (Y). Besarnya pengaruh prestasi belajar (X2) terhadap kreativitas (Y) adalah 11,42\%.

3. Nilai t-hitung pada variabel pelatihan (X3) sebesar 4,949 dengan tingkat signifikan kurang dari 5\% yaitu 0,000. Hal ini berarti pelatihan (X3) secara parsial berpengaruh signifikan terhadap kreativitas (Y).

Hasil tersebut di atas menunjukkan bahwa variabel pelatihan keja lebih dominan pengaruhnya terhadap kreativitas dibandingkan motivasi dan prestasi belajar.

\section{Pembahasan}

1. Pengaruh motivasi terhadap kreativitas siswa

Berdasarkan analisis data diperoleh hasil yang menunjukkan bahwa motivasi memiliki pengaruh yang signifikan terhadap kreativitas siswa. semakin tinggi motivasi siswa akan meningkatkan kreativitas siswa.

Hasil penelitian ini mendukung pendapat Maslow dan Atkinson dalam Slavin (2011: 102). Hasil penelitian ini juga sesuai dengan hasil penelitian terdahulu yang dilakukan oleh Yunus dan Ali (2009) serta Khuzaimah (2011) yang menunjukkan bahwa motivasi dapat berpengaruh positif dan signifikan terhadap variabel terikat yaitu prestasi belajar. Felissa dan Hadi (2012) yang menyimpulkan bahwa motivasi berpengaruh signifikan terhadap kreativitas siswa. Kuntjojo dan Matulessy (2012) menunjukkan bahwa ada hubungan positif yang sangat signifikan antara motivasi berprestasi dengan kreativitas.

Hasil penelitian ini sejalan dengan teori motivasi yang dikemukakan oleh Maslow dalam Slavin (2011) bahwa seseorang akan terdorong untuk melakukan sesuatu untuk memenuhi dan memuaskan kebutuhannya. Sedangkan Atkinson (Slavin, 2010: 110) mengemukakan bahwa dengan adanya keyakinan dalam upaya seseorang untuk berhasil tergantung pada harapan mereka terhadap imbalan yang diinginkan.

Adanya pengaruh motivasi terhadap kreativitas siswa disebabkan karena siswa memiliki motivasi yang tinggi, hal itu terbukti siswa antusias dalam memanfaatkan perpustakaan dan peralatan/sarana produktif dalam pembelajaran maupun dalam menyelesaikan tugas yang dibebankan oleh guru. Begitu juga dalam pembelajaran dikelas siswa mendengarkan penjelasan guru serta aktif dalam diskusi ataupun tanya jawab, segera mengaplikasikan teori yang diperoleh selam pembelajaran ke dalam bentuk praktek, Siswa juga mempunyai dorongan yang tinggi untuk berprestasi belajar secara baik dan lebih keras agar berhasil dalam pembelajaran dan mendapatkan nilai yang baik. Hal itu dilakukan dengan harapan memperoleh manfaat agar dapat mengembangkan kreativitasnya dengan kondisi belajar dan bekerja yang baik. Motivasi yang tinggi yang dimiliki siswa tersebut dapat memicu semangat siswa untuk berkreasi lebih baik.

Siswa tidak hanya termotivasi dalam pembelajaran tetapi juga melibatkan diri dalam lomba baik lomba yang bersifat akademik sesuai dengan bidang keahliannya maupun non 
akademik misalnya lomba tari, fashion show diantaranya pemilihan putri batik di tingkat daerah Pamekasan.

Kemampuan siswa memberikan semangat kepada diri sendiri untuk melakukan sesuatu yang baik dan bermanfaat mengandung makna adanya unsur harapan dan optimisme yang tinggi, sehingga seseorang memiliki kekuatan untuk melakukan suatu aktivitas tertentu. Misalnya dalam hal belajar, bekerja, menolong orang lain, dan sebagainya.

Hal itu sesuai dengan pendapat yang dikemukakan oleh Siagian (2007: 285) bahwa motivasi sebagai faktor yang menjadi pendorong tingkah laku yang menuntut atau mendorong orang untuk memenuhi suatu kebutuhan.

Motivasi dalam penelitian mempunyai pengaruh paling kecil diantara variabel prestasi belajar dan pelatihan kerja yaitu sebesar 7,95\%, berarti motivasi siswa untuk kreatif masih kecil. Hal ini disebabkan karena siswa yang kurang termotivasi/motivasi rendah mengeluarkan sterotip atau statemen-statemen negatif kepada siswa lain yang nampak rajin dan belajar dengan baik agar berhasil dalam pembelajaran sehingga motivasi siswa tersebut menjadi menurun.

Dengan demikian, berbagai upaya peningkatan motivasi yang dilakukan dapat meningkatkan kreativitas siswa. implikasi lain dari hasil penelitian ini adalah siswa memiliki minat, dan harapan mencapai tujuan yang diinginkan. Motivasi yang tinggi akan memberikan kontribusi pada meningkatnya kreativitas siswa. Hipotesis pertama yang menyatakan "diduga ada pengaruh signifikan motivasi terhadap kreativitas siswa" dapat diterima. Terbuktinya hipotesis pertama ini memberikan informasi bahwa semakin tinggi motivasi yang dimiliki siswa maka akan semakin tinggi pula kreativitas siswa dan sebaliknya, motivasi yang rendah akan menyebabkan kreativitas siswa juga rendah atau menurun.

\section{Pengaruh prestasi belajar terhadap kreativitas siswa}

Berdasarkan analisis data diperoleh hasil yang menunjukkan bahwa prestasi belajar memiliki pengaruh yang signifikan terhadap kreativitas siswa. Hal ini berarti semakin baik prestasi belajar maka kreativitas siswa akan semakin meningkat. Sebaliknya semakin rendah prestasi belajar maka kreativitas siswa akan menurun.

Hasil penelitian ini mendukung teori yang dikemukakan oleh Hamalik (2000). Hasil penelitian ini juga sesuai dengan hasil penelitian terdahulu yang dilakukan oleh Cheng (2006) menunjukkan bahwa web-based collaborative learning instruction meningkatkan kreativitas bisnis mahasiswa. Lestari, Harnanik, dan Hadi (2012) dalam konsep yang berbeda menunjukkan bahwa prestasi belajar berpengaruh terhadap minat berwirausaha siswa, salah satu karakterisik seorang wirausaha adalah kreatif.

Hamalik (2000) menyatakan bahwa prestasi belajar yang dicapai oleh peserta didik menunjukkan adanya suatu perubahan atau pertumbuhan dalam diri siswa hal itu nampak dari cara berperilaku baru berkat adanya pengalaman dan latihan. Perilaku itu dapat berupa pengertian, sikap, penghargaan, dan kecakapan.

Prestasi belajar dalam penelitian ini diperoleh dari nilai rata-rata rapor pada mata diklat produktif kelas XI semester IV. Prestasi belajar mencerminkan penguasaan siswa terhadap materi mata diklat produktif baik berupa teori maupun praktek, yaitu sejauh mana siswa dapat mengaplikasikan teori yang diperoleh selama pembelajaran ke dalam bentuk praktek. Pengaruh prestasi belajar lebih tinggi dibandingkan motivasi. Hal ini dikarenakan siswa yang mencapai prestasi belajar lebih dari 75 yaitu sebanyak 56 dari 68 orang $(82,35 \%)$ dan termasuk kategori baik, sesuai dengan predikat yang tercantum di rapor, 
baiknya prestasi belajar siswa menunjukkan bahwa siswa yang bersangkutan menguasai pengetahuan dan keterampilan dengan baik atau kompeten dalam mata diklat produktif. Hal itu tidak terlepas dari upaya guru produktif yang selalu memperhatikan siswa dengan memberikan bimbingan yang baik terhadap siswa. Hal tersebut sesuai dengan pernyataan yang disampaikan oleh Tu'u (2004: 75) bahwa prestasi belajar adalah penguasaan pengetahuan atau keterampilan yang dikembangkan oleh mata pelajaran, lazimnya ditunjukkan dengan nilai tes atau angka nilai yang diberikan oleh guru.

Berdasarkan uraian diatas semakin menguatkan bahwa prestasi belajar berpengaruh signifikan dan positif terhadap kreativitas siswa SMKN 3 Pamekasan. Terbuktinya hipotesis kedua ini memberikan informasi bahwa semakin tinggi pencapaian prestasi belajar mata diklat produktif yang menunjukkan semakin baiknya pengetahuan dan keterampilan yang dimiliki siswa maka akan semakin tinggi pula kreativitas siswa dan sebaliknya, prestasi belajar yang dicapai siswa rendah akan menyebabkan kreativitas siswa juga rendah.

\section{Pengaruh pelatihan kerja terhadap kreativitas siswa.}

Berdasarkan analisis data diperoleh hasil yang menunjukkan bahwa pelatihan kerja memiliki pengaruh yang signifikan terhadap kreativitas siswa. Hal ini berarti semakin baik hasil dari pelatihan kerja maka kreativitas siswa akan semakin meningkat. Sebaliknya semakin rendah hasil pelatihan kerja maka kreativitas siswa akan menurun.

Hasil penelitian ini mendukung teori yang dikemukakan oleh Gomes (1997: 197). Sesuai dengan penelitian terdahulu yang dilakukan oleh Muslimah (2011) yang menunjukkan keberhasilan prakerin karena penguasaan mata diklat produktif akuntansi. Mariati (2006) yang menyimpulkan bahwa menunjukkan bahwa pertanyaan divergen dalam latihan dan kegiatan pembelajaran dapat mengembangkan kreativitas siswa. Penelitian Lestari, Harnanik dan Hadi (2012) dalam konsep yang berbeda menunjukkan bahwa prakerin berpengaruh terhadap minat berwirausaha siswa. Begitu juga dengan penelitian yang dilakukan Karyono (2009) menyimpulkan bahwa lama prakerin secara tidak langsung melalui motivasi belajar memberikan kontribusi signifikan terhadap sikap kewirausahaan.

Menurut Gomes (1997: 197) pelatihan sebagai suatu usaha untuk memperbaiki prestasi kerja pada suatu pekerjaan tertentu yang sedang menjadi tanggung jawabnya. Idealnya, pelatihan harus dirancang untuk mewujudkan tujuan-tujuan organisasi, yang pada waktu bersamaan juga mewujudkan tujuan-tujuan para pekerja secara perorangan.

Pelatihan kerja dalam penelitian ini adalah program prakerin untuk siswa dengan tujuan siswa dapat mengenal dunia kerja dengan baik. Pelatihan merupakan salah satu metode yang memungkinkan terjadinya proses belajar untuk meningkatkan kreativitas. Karena salah satu tujuan pelaksanaan prakerin adalah untuk mencetak siswa yang memiliki keahlian professional, yaitu tenaga kerja yang memiliki tingkat pengetahuan, keterampilan, dan etos kerja yang sesuai dengan tuntutan lapangan kerja.

Berdasarkan data responden tentang praktek kerja industri (prakerin) yaitu nilai yang dicapai siswa di tempat prakerin menunjukkan bahwa sebagian besar nilai pakerin yang diperoleh siswa adalah lebih dari 75 yaitu sebanyak 57 dari 68 orang $(83,82)$ dan termasuk dalam kategori baik tingginya nilai prakerin yang diperoleh siswa menunjukkan tingkat keberhasilan pelaksanaan prakerin yang baik. Keberhasilan pelaksanaan prakerin siswa dari nilai yang dicapai menunjukkan bahwa teori yang diterima siswa disekolah dapat diaplikasikan dengan baik didunia kerja atau industri, dan sesuai dengan pakem yang ada 
di industri sehingga siswa tersebut menjadi lebih siap untuk terjun ke dunia kerja. Hal tersebut sesuai dengan yang dikemukakan Rae dalam Sofyandi (2008) bahwa pelatihan dilakukan untuk meningkatkan pengetahuan dan kemampuan karyawan (dalam hal ini siswa) dalam melaksanakan tugas dan pekerjaannya, sehingga lebih efektif dan efisien. Dalam penelitian ini pelatihan kerja (prakerin) dapat memberikan rangsangan/stimulus kepada seseorang untuk meningkatkan kemampuan dalam pekerjaan tertentu dan memperoleh pengetahuan umum dan pemahaman terhadap keseluruhan lingkungan kerja dan organisasi. Sangat dimungkinkan bahwa pelatihan kerja (prakerin) dapat mempengaruhi dan meningkatkan kreativitas siswa karena meningkatnya pengetahuan dan skill siswa akan mendorong mereka untuk berkreasi dengan lebih baik.

Penilaian yang dilakukan untuk menilai keberhasilan prakerin meliputi beberapa kriteria yaitu produksi dan jasa, kreativitas, kedisiplinan, kerja sama, tanggung jawab, sikap, inisiatif, dan kerajinan. Kriteria yang memberi pengaruh pada kreativitas siswa adalah kreativitas, kedisiplinan, kerjasama, dan inisiatif karena hal itu dapat membentuk sikap dan karakter siswa agar memiliki pola pikir kreatif. Hal itu sesuai dengan penelitian yang dilakukan oleh Munandar tahun 1977 (Munandar, 2004: 37) yang menyatakan ciri-ciri pribadi kreatif meliputi: penuh energi, mempunyai prakarsa, percaya diri, sopan, rajin, melaksanakan pekerjaan pada waktunya, sehat, berani dalam berpendapat, mempunyai ingatan yang baik, dan ulet.

Berdasarkan uraian diatas semakin memperkuat penelitian ini bahwa pelatihan kerja (prakerin) berpengaruh signifikan terhadap kreativitas siswa SMKN 3 Pamekasan. Terbuktinya hipotesis ketiga ini memberikan informasi bahwa semakin tinggi nilai evaluasi pelatihan kerja (prakerin) siswa yang menunjukkan keberhasilan prakerin yang diikuti siswa maka akan semakin tinggi pula kreativitas siswa dan sebaliknya, nilai evaluasi pelatihan kerja (prakerin) siswa rendah maka kreativitas siswa juga rendah.

\section{Pengaruh motivasi, prestasi belajar, dan pelatihan kerja terhadap kreativitas siswa}

Berdasarkan analisis data diperoleh hasil yang menunjukkan bahwa motivasi, prestasi belajar, dan pelatihan kerja secara simultan atau bersama-sama memiliki pengaruh signifikan terhadap kreativitas siswa. implikasi dari penelitian ini adalah semakin baik motivasi, prestasi belajar, dan pelatihan kerja maka kreativitas siswa semakin baik. Sebaliknya semakin rendah motivasi, prestasi belajar, dan pelatihan kerja maka kreativitas siswa juga semakin rendah. Hal ini sesuai dengan penelitian yang dilakukan oleh Felissa dan Hadi (2012) yang menyatakan bahwa motivasi berpengaruh signifikan terhadap kreativitas siswa. Lestari, Harnanik dan Hadi (2012) menyimpulkan bahwa prestasi belajar dan pelatihan kerja berpengaruh signifikan terhadap minat berwirausaha siswa. Cheng (2006) menunjukkan bahwa web-based collaborative learning instruction meningkatkan kreativitas bisnis mahasiswa.

Siswa dalam mengikuti pembelajaran di sekolah tidak hanya bagaimana menguasai teori seperti yang diberikan oleh guru maupun dari literatur dan sumber lain seperti internet tetapi juga bagaimana mengaplikasikan teori yang diterima kedalam bentuk praktek. Salah satu indikasi siswa yang berpikir kreatif adalah siswa yang mempunyai keyakinan dan mampu memecahkan masalah dengan baik. Kreatif dan inovatif dalam membuat produk maupun dalam menyediakan jasa dan bagaimana memecahkan masalah (problem solving) atas tugas yang diberikan oleh guru.

Setiap orang diasumsikan memiliki kemampuan kreatif meskipun dengan tingkat 
yang beragam. Kreativitas seseorang berkembang dipengaruhi oleh faktor-faktor internal (diri sendiri) dan eksternal (lingkungan). Kreativitas dapat dikembangkan baik melalui lingkungan sekolah maupun di lingkungan keluarga. Pengembangan dan pembaharuan di berbagai bidang dapat dilakukan jika berhasil dimunculkan gagasan-gagasan baru yang dihasilkan oleh individu yang kreatif

Kreativitas siswa dapat juga dikembangkan melalui ketertarikan dan keingintahuan yang besar terhadap hal-hal baru yang diiringi dengan mengajukan pertanyaan berbobot yang bersifat membangun agar dapat menyelesaikan tugas dengan baik. Dengan demikian siswa dapat lebih berkreasi dalam membuat suatu karya/produk. Untuk menjadi kreatif siswa membutuhkan sedikit kesempatan atau waktu bebas untuk bermain-main dengan gagasan atau konsep yang dipahaminya.

Guru sebagai kunci pendidikan dan motivator bagi siswa mempunyai peranan penting dalam mengantarkan peserta didiknya menuju keberhasilan. Adanya upaya guru dalam membantu siswa untuk meningkatkan kreativitasnya serta penempatan pelatihan kerja (prakerin) yang disesuaikan dengan bidang keahlian siswa dapat mendorong siswa untuk mengembangkan dan meningkatkan kreativitasnya.

Hasil penelitian ini menunjukkan bahwa motivasi yang dimiliki siswa cenderung tinggi namun berpengaruh paling kecil terhadap kreativitas siswa. Prestasi belajar mata diklat produktif siswa dan hasil evaluasi pelatihan kerja (prakerin) cenderung baik sehingga pengaruhnya terhadap kreativitas lebih tinggi dibandingkan motivasi. Hal ini didukung teori menurut Robert Weisberg (Tilaar, 2012: 63) yang memberikan suatu definisi kerja bahwa berfikir kreatif terjadi apabila secara intensional seseorang menghasilkan suatu produk baru atau ketika dia melaksanakan suatu tugas. Hal ini berarti bahwa suatu produk kreativitas dapat dihasilkan oleh seseorang yang mempunyai pengalaman tertentu. Dengan demikian hipotesis keempat yang berbunyi "diduga ada pengaruh signifikan motivasi, prestasi belajar, dan pelatihan kerja terhadap kreativitas siswa" dapat diterima.

\section{KESIMPULAN}

Adapun kesimpulan yang dapat diambil dari hasil analisis regresi linier berganda dan pembahasan adalah sebagai berikut :

1. Motivasi mempunyai pengaruh yang signifikan dan positif terhadap kreativitas siswa SMKN 3 Pamekasan. Motivasi siswa SMKN 3 Pamekasan yang dikaji melalui 3 indikator yaitu kebutuhan, dorongan dan harapan, menunjukkan rata-rata variabel dalam kategori tinggi, sehingga setiap peningkatan dari motivasi akan diikuti dengan meningkatnya kreativitas siswa.

2. Prestasi belajar mempunyai pengaruh yang signifikan dan positif terhadap kreativitas siswa SMKN 3 Pamekasan. Prestasi belajar siswa SMKN 3 Pamekasan yang dikaji melalui nilai rata-rata rapor prestasi belajar mata diklat produktif semester IV termasuk dalam kategori baik. Hal ini berarti bahwa setiap peningkatan dari prestasi belajar akan diikuti oleh meningkatnya kreativitas siswa.

3. Pelatihan kerja mempunyai pengaruh yang signifikan dan positif terhadap kreativitas siswa SMKN 3 Pamekasan. Pelatihan kerja siswa SMKN 3 Pamekasan yang dikaji melalui nilai pakerin yang dilakukan di Unit Produksi dan Jasa (UPJ) sekolah, nilai prakerin siswa termasuk dalam kategori baik. Hal ini berarti bahwa setiap pen- 
ingkatan dari pelatihan kerja akan diikuti oleh meningkatnya kreativitas siswa.

4. Motivasi, prestasi belajar dan pelatihan kerja secara bersama-sama (simultan) mempunyai pengaruh yang signifikan dan positif terhadap kreativitas siswa SMKN 3 Pamekasan. Kreativitas siswa SMKN 3 Pamekasan yang dikaji melalui dua belas indikator yaitu rasa ingin tahu, mengajukan pertanyaan, memberikan gagasan, menyatakan pendapat, Menghargai keindahan, pendapat sendiri, humor, imajinasi, pemikiran orisinil, bekerja sendiri, mencoba hal-hal baru, kemampuan elaborasi, menunjukkan rata-rata variabel yang termasuk dalam kategori tinggi. Jadi setiap peningkatan dari motivasi, prestasi belajar, dan pelatihan kerja akan diikuti oleh meningkatnya kreativitas siswa.

Berdasarkan hasil yang diperoleh dalam penelitian ini maka saran yang dapat direkomendasikan adalah sebagai berikut :

1. Pengaruh motivasi terhadap kreativtias siswa adalah yang terrendah diantara variabel lain, maka dari itu siswa diharapkan meningkatkan motivasi dalam mengikuti pembelajaran agar mereka mempunyai bekal pengetahuan yang cukup untuk mengikuti praktek kerja industri sehingga tidak terjadi kesenjangan antara teori dan praktek. Dengan demkian siswa akan lebih mudah mengasah kreativitas siswa.

2. Pihak sekolah hendaknya tetap memberikan kesempatan kepada siswa untuk mengikuti praktek kerja industri (prakerin) di Unit Produksi dan Jasa (UPJ) sekolah sehingga siswa akan lebih mudah beradaptasi dengan lingkungan serta mendapat pengawasan langsung dari guru.

3. Penelitian ini dilakukan di satu sekolah, bagi peneliti selanjutnya hendaknya melakukan penelitian pada saat praktek kerja industri (prakerin) dengan instansi yang lebih banyak lagi, serta melakukan penelitian yang lebih spesifik pada jurusan tertentu agar hasil yang diperoleh lebih detil.

4. Teknik pengumpulan data untuk variabel pelatihan kerja dalam penelitian ini diperoleh dari data sekunder (dokumentasi) untuk mendapatkan nilai prakerin. Peneliti selanjutnya diharapkan melengkapi data prakerin dengan data primer misalnya dengan menggunakan angket yang langsung ditujukan kepada siswa. Sehingga data yang diperoleh benar-benar menggambarkan tingkat keberhasilan siswa dalam mengikuti prakerin.

5. Prestasi belajar dan pelatihan kerja terhadap kreativitas siswa perlu diteliti lebih lanjut karena masih belum ditemukan dalam penelitian terdahulu. Peneliti selanjutnya diharapkan meneliti motivasi yang lebih ditekankan pada anggapan sterotip bahwa perempuan tidak harus belajar lebih tinggi.

6. Kreativitas sebagai suatu pola fikir kreatif dalam menghasilkan produk baru maupun gagasan-gagasan baru dipengaruhi oleh faktor internal (diri sendiri) dan faktor eksternal (lingkungan). Penelitian ini hanya meneliti pada faktor-faktor tertentu saja, untuk itu diharapkan kelak bagi para peneliti bisa meneliti faktor-faktor lainnya yang mempengaruhi kreativitas siswa yang tidak terjangkau dalam penelitian ini, misalnya minat siswa, kepercayaan diri (self efficacy), ataupun faktor lingkungan dan keluarga. 


\section{DAFTAR RUJUKAN}

Akhmad Karyono. 2009. Kontribusi Status Tempat Prakerin, Lama Prakerin dan Motivasi Belajar Terhadap Sikap Kewirausahaan Siswa SMK di Kabupaten Indramayu. Teknologi dan Kejuruan, Vol. 32, No. 2, September 2009. (http://journal.um.ac.id/index.php/teknologi-kejuruan/article/view/3098/458).

Craft, Ana. 2005. Membangun Kreativitas Anak. Depok : Insani Perss

Cheng, Kevin K.W. 2006. The Comparative Effect on Business Creativity When Web based Collaborative Learning vs. Traditional Lecturing Instruction. Research in Higher Educational Journal. Volume 2. (www.aabri.com/manuscripts/08115.pdf).

Dikmenjur. (2008). Kurikulum SMK. Jakarta: Dikmenjur.

Fadlilah, Nur. 2011. Pengaruh Motivasi Belajar Terhadap Prestasi Belajar Pada Mata Diklat Mail Handling. Jurnal Pendidikan Ekonomi. Vol. 4, No. 2, Oktober 2011.

Felissa, Juniar dan Hadi, Samsul. 2012. Pengaruh Motivasi Mengikuti Ekstrakurikuler Robotika Terhadap Kemampuan Penalaran dan Kreativias Siswa Di SMK N 3 Yogyakarta. Jurnal Pendidikan Teknik Mekatronika. Vol 1, No. 2, November 2012. (http:// journal.student.uny.ac.id/jurnal/artikel/1758/48/263).

Gomez, Faustino Cardosa. 1997. Manajemen Sumber Daya Manusia. Yogyakarta : Andi Offset.

Hamalik, Oemar. 2000. Psikologi Belajar dan Mengajar. Bandung: Sinar Utama Algesindo.

Hariandja, Marihot T. Efendi. 2002. Manajemen Sumber Daya Manusia. Jakarta : PT. Gramedia Widisarana Indonesia.

Hasibuan, Malayu. 2007. Manajemen Sumber Daya Manusia. Jakarta: Bumi Aksara.

Khuzaimah, Riani. 2011. Pengaruh Gaya Mengajar Guru Dan Motivasi Belajar Siswa Terhadap Prestasi Belajar Siswa Pada mata pelajaran Akuntansi. Jurnal Pendidikan Ekonomi. Vol. 4, No. 2, Oktober 2011.

Kuntjojo dan Matulessy, Andik. 2012. Hubungan Antara Metakognisi Dan Motivasi Berprestasi Dengan Kreativitas. Jurnal Psikologi Persona Volume 01 Nomor 01 Juni 2012. (http://drmasda.wordpress.com)

Lestari, Harnanik, dan Hadi. 2012. Pengaruh Prakerin, Prestasi Belajar dan Lingkungan Keluarga Terhadap Minat Berwirausaha siswa. Economic Education Analysis Journal. Vol 1, No 2 (2012). (http://journal.unnes.ac.id/sju/index.php/eeaj/article/view/541/588).

Mariati. 2006. Pengembangan Kreativitas Siswa melalui Pertanyaan Divergen pada Mata Pelajaran llmu Pengetahuan Alam (IPA). Jurnal Pendidikan dan Kebudayaan, No. 063, Tahun ke-12, November 2006. (http://isjd.pdii.lipi.go.id/admin/jurnal/126306759773. pdf).

Munandar, Utami. 2004. Pengembangan Kreativitas Anak Berbakat. Jakarta: Rineka Cipta.

Muslimah. 2011. Keberhasilan Prakerin Karena Penguasaan Mata Diklat Produktif Akuntansi dan Minat Siswa di SMK. Jurnal Pendidikan Ekonomi. Vol. 3, No. 3, Febru- 
ari 2011.

Rivai, Veithzal. 2004. Manajemen Sumber Daya Manusia untuk Perusahaan, Dari Teori ke Praktik. Jakarta : PT Raja Grafindo Persada.

Siagian, P Sondang, 2007. Manajemen Sumber Daya Manusia. Jakarta: Bumi Aksara.

Slavin, E. Robert. 2011. Psikologi Pendidikan Teori dan Praktik. Edisi kesembilan. Jakarta: PT Indeks Permata Puri Media.

Sofyandi, Herman. 2008. Manajemen Sumber Daya Manusia. Edisi pertama. Yogyakarta : Graha Ilmu

Syah, Muhibbin. 2007. Psikologi Belajar. Jakarta : PT RajaGrafindo Persada

Tilaar, H. A. R. 2012. Pengembangan Kreativitas dan Entrepreneurship. Jakarta : PT Kompas Media Nusantara.

Tu'u, Tulus. 2004. Peran Disiplin Pada Perilaku dan Prestasi Siswa. Jakarta: Grasindo.

Yunus, Aida Suraya Md. dan Ali, Wan Zah Wan. 2009. Motivation in the Learning of Mathematics. European Journal of Social Sciences. Volume 7, Number 4 (2009). (www. eurojournals.com/ejss_7_4.pdf). Diakses 30 Juli 2012. 